\title{
Plant and microbe genomics and beyond: potential for developing a novel molecular plant nutrition approach
}

\author{
Fernando Carlos Gómez-Merino ${ }^{1}$ Libia Iris Trejo-Téllez ${ }^{2} \cdot$ Alejandro Alarcón $^{2}$
}

Received: 9 August 2014/Revised: 21 June 2015/Accepted: 26 August 2015/Published online: 18 September 2015

(C) The Author(s) 2015. This article is published with open access at Springerlink.com

\begin{abstract}
Classical soil science approaches have enabled us to establish basic principles of how the soil system functions and have answered numerous practical agricultural application questions. In recent years, efforts have been refocused on better understanding, managing and benefiting from this system that contains one of the most complex biological communities of the planet. Soil biology is seen as being at the center of scientific research of this century, with novel research objectives and goals being set. In addition, plant nutrition has enabled us to understand nutrient uptake, transport and mobilization mechanisms in plants, and both disciplines have converged on the area of microorganism-mediated plant nutrition. The challenge for these scientific areas is to identify microorganism communities and the roles they play in their habitats, as well as the mechanisms that plants have to make better use of nutrients. Genomics and metagenomics, along with microbiological techniques, are contributing greatly to advances in our understanding of living systems that exist in the soil and their interaction with plants. For its part, molecular plant nutrition has made significant progress in understanding the use of nutrients by plant cells, and has identified molecular mechanisms that can improve nutrient use efficiency. Together, molecular soil microbiology and
\end{abstract}

Communicated by A. K. Kononowicz.

Fernando Carlos Gómez-Merino

fernandg@colpos.mx; fcgmerino@gmail.com

1 Colegio de Postgraduados Campus Córdoba, Carretera Córdoba, Veracruz 348, Congregación Manuel León, Mpio. de Amatlán de los Reyes, Veracruz C. P. 94946, Mexico

2 Colegio de Postgraduados Campus Montecillo, Carretera México-Texcoco km 36.5, Montecillo, Mpio de Texcoco, State of Mexico C. P. 56230, Mexico molecular plant nutrition are projected to be a driving force in agriculture and sustainable food production in the coming years. Herewith, we aim to integrate recent literature on basic and applied research concerning plant and microbe genomics in terms of their potential for developing a novel molecular plant nutrition approach, with special emphasis on nitrogen, potassium and phosphorous as the major macronutrients for crop plants.

Keywords Life sciences - Molecular microbiology · Nutrients $\cdot$ Soil science $\cdot$ Innovation

\section{Introduction}

In the traditional approach, soil science includes studies in physics, chemistry, mineralogy, biology, and taxonomy to understand the processes that affect nutrient retention and release, the impact of pollutants and water availability, all of which significantly influence the soil-plant system. This interdisciplinary area also encompasses the study of the diversity of organisms in the soil and in the rhizosphere of plants, as well as their contribution to the recycling of organic material and their functions in regulating the availability, mobility, and use of nutrients by plants (Kutílek and Nielsen 2015). Importantly, the rhizosphere soil microbiome is influenced by a complex and nested array of factors at varying spatial scales, including plant community, plant host, soil edaphic and microbial taxon and community characteristics (Bakker et al. 2014). By studying such processes, it is possible to provide crucial information related to soil use and management that results in improved soil fertility and quality based on physical, chemical, and biological aspects; at the same time, such studies lead to the generation of practices aimed at better soil utilization, protection, 
conservation, rehabilitation and remediation (Lindbo et al. 2012). Therefore, efficient integrated plant nutrition management represents one of the most critical factors for achieving sustainable agriculture and food security.

Plant nutrition is related to mineral metabolism, the physiology of crop yield, the optimal use of organic and mineral fertilization, and plant quality and health. According to FAO (2006), plant nutrient requirements can best be supplied through an integrated use of diverse nutrient resources, taking advantage of a combined and harmonious application of organic, mineral and biofertilizer nutrient inputs. This approach may serve the concurrent needs of food production, and economic, environmental and social viability. Consequently, this concept strives to ensure ecosystem sustainability against nutrient mining and degradation of soil and water resources, and enable a reasoned way to balance efficient use of limited or finite fertilizer resources. Among major plant nutrients, nitrogen $(\mathrm{N})$ is abundant in the air, while potassium (K) deposits are considerable (López-Arredondo et al. 2014; Véry et al. 2014); however, phosphorous (P) reserves will become scarce (Cordell et al. 2011). Although a general claim has explicitly drawn attention to the challenges presented by global phosphorus scarcity (Cordell and White 2011), there is still a lack of policy debate and action concerning strict rules for recycling and efficient use of $\mathrm{P}$. To bridge these gaps, a general scientific and political effort to provide support to the ongoing attempts directed at enhanced and sustainable agricultural production based on integrated plant nutrient management is needed.

Plant nutrition has made significant progress, thanks to advances in molecular biology (von Wirén 2011). Improved understanding of plant-microbe interactions and advances in molecular biology applied to soil microbiology have led to the emergence of areas such as molecular microbiology, soil metagenomics and molecular plant nutrition (Rincon-Florez et al. 2013).

In this review, we analyze the most salient advances in molecular technologies used for the study of soil biology and plant nutrition, and discuss areas of opportunity that should be covered with the support of the genomic sciences to make more efficient use of nutrient sources, under a sustainable agriculture approach. Unfortunately, it was not possible in this review, due to space limitations, to reference all of the valuable contributions made in this area.

\section{Molecular techniques for the study of functional groups of soil microorganisms}

Soil microbial activity is critical to the maintenance of life on Earth, as it is responsible for the mineralization of organic material, influencing nutrient recycling and availability and consequently plant bioremediation and nutrition processes. Microorganisms that inhabit the soil make up very diverse populations and with recent advances in molecular biology even more complex levels of diversity have been discovered (Rastogi and Sani 2011).

Currently, through techniques that omit the use of artificial media for microbiological studies, it is possible to analyze the microbial composition of certain environments, especially when it comes to microorganisms that cannot be cultured ex situ. A recent review published by RinconFlorez et al. (2013) describes three groups of culture-independent techniques for analyzing the biomass, diversity and catabolic activity of microbial communities. The first group encompasses eight techniques based on PCR: DDGE/TGGE (Kirk et al. 2004; Dowd et al. 2008; Cleary et al. 2012), T-RFLP (Kakavas et al. 2008), SSCP (Nocker et al. 2007), ARISA/RISA (Kirk et al. 2004), LH-PCR (Okubo and Sugiyama 2009; Mills et al. 2007), RAPD (Fritsch and Rieseberg 1996; Newbury and Ford-Lloyd 1993), ARDRA (Nocker et al. 2007) and q-PCR (Smith and Osborn 2009). The second group includes six techniques not based on PCR: CFE (Alessi et al. 2011; Ocio and Brookes 1990), PLFA (Zhang et al. 2007), FDA (Adam and Duncan 2001; Green et al. 2006), SIP (Dumont and Murrell 2005), DNA arrays (Li and Liu 2003) and FISH (Moter and Göbel 2000). Finally, high-throughput sequencing technologies comprise six techniques: 454 (Mardis 2008), Illumina (Loman et al. 2012), SOLiD (Magi et al. 2010; Shokralla et al. 2012), PGM (Egan et al. 2012; Loman et al. 2012), HeliScope (Magi et al. 2010; Shokralla et al. 2012) and SMRT (Schadt et al. 2010). Some of these techniques are also applied to the study of plant genomics.

Since most soil prokaryotes are not able to grow on artificial culture media (Stewart 2012), beginning with the discovery of molecular markers such as phospholipid fatty acids (PLFA) and nucleic acids (DNA and RNA) (Insam 2001; Kirk et al. 2004), significant progress has been made in their study. The combined use of different molecular techniques based on the small-subunit rRNA has generated important data on the diversity, structure and dynamics of microbial communities (Rastogi and Sani 2011; Rajendhran and Gunasekaran 2008). For example, DNA-based molecular studies have shown that clone libraries constructed from soil can be composed almost entirely of single members of microbial communities (Zhou et al. 2002). In fact, Fierer et al. (2007) reported that archaeal and fungal communities were consistently less even than bacterial communities were. The vast majority of communities are scarce, and a few are the most abundant, suggesting that there are competitive interactions that determine their structures (Zhou et al. 2002), especially in saturated soils, compared to surface soils, where there is no dominant competition between communities. Two of the 
characteristics that promote this diversity are the stability of soil moisture in deeper layers, and the high competition for carbon sources that are not as abundant as in surface layers; moreover, it has also been shown that the diversity of microorganisms increases with decreasing soil particle size (Sessitsch et al. 2001).

Microarrays have enabled the analysis of large volumes of data to detect gene expression or find the presence of array sequences in a given experimental sample (Murray et al. 2001; Chang et al. 2008). Thus, different types of microarrays (open reading frame arrays for complete genomes, phylogenetic oligonucleotide arrays, community genome arrays, metagenomic arrays, and functional gene arrays such as GeoChip arrays) have been developed to examine microbial populations either in natural ecosystems or with different degrees of disturbance (Van Nostrand et al. 2011). These techniques represent specific, sensitive and rapid tools for analyzing microbial communities from different environmental samples (He et al. 2012). Using such tools it has been shown that the bacterial community, in terms of diversity, changes depending on the type of soil (considering its $\mathrm{pH}$, nutrient availability, oxygenation, dominant flora, leaf litter decomposition rates, rhizosphere/ mycorrhizosphere, etc.) (Prescott and Grayston 2013). Thus, Russo et al. (2012) demonstrated that analysis of $16 \mathrm{~S}$ $r R N A$ genes by PhyloChip microarrays showed that the richness of bacteria is greater in clay soil (Acidobacteria group) compared to sandy-loam soil (Proteobacteria class); however, the bacterial classes Actinobacteria, Betaproteobacteria, Clostridia, Bacilli, and Gammaproteobacteria were more abundant in sandy-loam soil.

Davinic et al. (2012) analyzed the bacterial diversity in soil macro- and micro-aggregates, showing that each microenvironment hosts a different bacterial community. Thus, macroaggregates with high carbon content showed abundance of Actinobacteria (excluding the order Rubrobacteriales) and $\alpha$-Proteobacteria; by contrast, microaggregates showed greater abundance of Rubrobacteriales and a lower amount of organic carbon.

Through pyrosequencing of $16 S$ - and $18 S$-rRNA genes, Bastida et al. (2013) determined that the structure of bacterial and fungal communities showed variations in response to the presence or absence of organic amendments. The number of $\alpha$-Proteobacteria sequences was higher than that of Actinobacteria sequences in soils with high amendment application. As for fungi, Ascomycota sequences responded positively to restoration.

Beyond the genome and metagenome (the whole genetic material from an environmental sample), analysis of the proteome and metaproteome contributes to our understanding of the microbial biodiversity in the soil/rhizosphere and their functions in aspects related to plantmicroorganism molecular dialog, plant nutrition and nutrient recycling (Badri et al. 2009; Xiong et al. 2013; Renella et al. 2014).

To support the annotation, analysis and distribution of microbial genome and metagenome datasets, the US Department of Energy Joint Genome Institute (DOE JGI) created The Integrated Microbial Genome (IMG) system, which is also open to the scientific community worldwide (Markowitz et al. 2014). The IMG data warehouse integrates genomes from all three domains of life, as well as plasmids, viruses and genome fragments. IMG provides tools for analyzing and reviewing the structural and functional annotations of genomes in a comparative context. Different IMG datamarts provide support for the analysis of publicly available genomes (IMG/W: http://img.jgi.doe. gov/w), expert review of genome annotations (IMG/ER: http://img.jgi.doe.gov/er) and teaching and training in the area of microbial genome analysis (IMG/EDU: http://img. jgi.doe.gov/edu).

According to the IMG platform, in May 2015 there were 8257 sequenced microbial genomes, of which 3404 correspond to bacteria, 199 to archaea, 31 to eukaryota, 1186 to plasmids and 3348 to viruses (Table 1). In total, 98,482,933 genes have been sequenced.

Furthermore, the Community Cyberinfrastructure for Advanced Microbial Ecology Research and Analysis (CAMERA, http://camera.calit2.net/) is a database and associated computational infrastructure that provides a single system for depositing, locating, analyzing, visualizing and sharing data about microbial biology through an advanced web-based analysis portal (Sun et al. 2011) which substantially supports any initiative related to environmental microbiology, including microbial-mediated plant nutrition.

Going higher up in the complexity of sequencing projects, metagenomes of microbial communities are derived from complex processes of direct DNA extraction from microorganisms inhabiting ecosystems, with which metagenomic libraries are constructed. Metagenomic libraries contain the entirety of information on the integral genetic capacity of biological systems, including communities composed of a multitude of species, which are easily accessible for other experiments and applications. Figure 1 shows the overall process for analyzing environmental samples either through the construction of libraries or through direct sequencing of total DNA for subsequent assembly using bioinformatics tools (Lasken 2012; Lorenz and Eck 2005).

Metagenomic applications enable us to not only understand the molecular processes that generate biodiversity, but also to recreate them in experimental conditions for detailed study of nutrient uptake and transport processes, to cite one example. Microbial communities in the plant rhizosphere are crucial in the processing of nutrients that the 
Table 1 Microbial genomes sequenced, in the process of being sequenced or drafts (Version 4.520 April 2015)
Fig. 1 Metagenomic analyses of environmental samples either by direct sequencing of lysed DNA or by constructing metagenomic libraries containing DNA cloned into different vectors

\begin{tabular}{lrrrr}
\hline Category & Sequenced genomes & Genomes in the process of sequencing & Drafts & Total \\
\hline Bacteria & 3404 & 2526 & 19,941 & 25,871 \\
Archaea & 199 & 15 & 318 & 532 \\
Eukaryota & 31 & 37 & 122 & 190 \\
Plasmids & 1186 & 0 & 0 & 1186 \\
Viruses & 3348 & 53 & 487 & 3888 \\
Genomic fragments & 89 & 0 & 1103 & 1192 \\
Total & 6937 & 3228 & 21,971 & 32,859 \\
\hline
\end{tabular}

Considering the Integrated Microbial Genomes database (http://img.jgi.doe.gov/cgi-bin/edu/main.cgi?sec tion=ImgStatsOverview\#tabview=tab0)

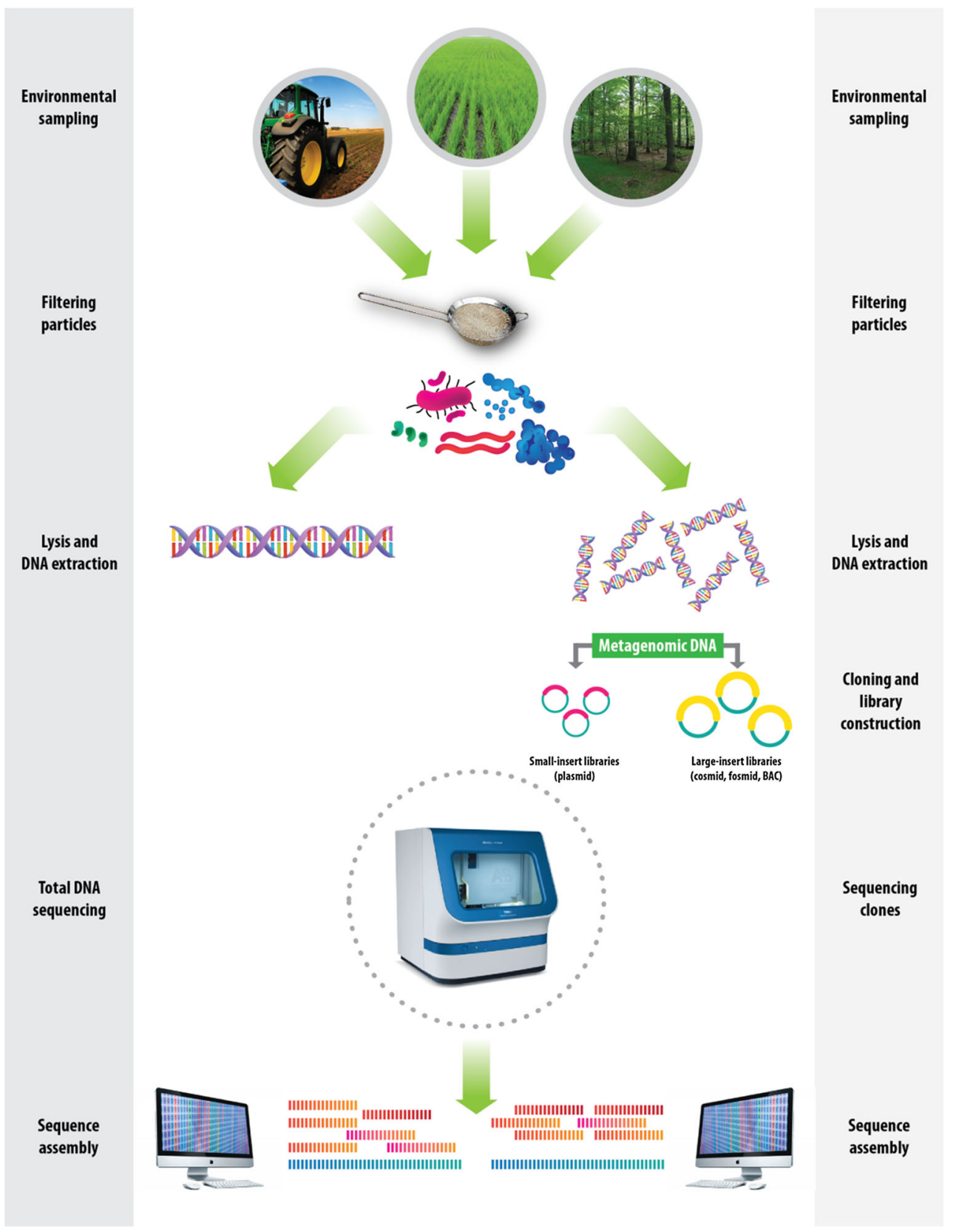


root can absorb and transport. Certain bacteria convert atmospheric nitrogen into ammonia. Some soil organisms recycle nutrients from the remains of plants and animals, while others convert elements such as $\mathrm{Fe}$ and $\mathrm{Mn}$ into forms that can be used by the plant. Furthermore, no microorganism can convert ammonium to nitrate in isolation, but groups of them can do so efficiently. This demonstrates the potential that microbial communities can have in processes essential for life such as biotransformations in soil (Alarcón et al. 2012).

The applications being developed and those that can only be glimpsed now have immense potential. Therefore, the changes that lie ahead with these advances will place soil science and crop nutrition research in a new era of development. With these technologies, it is possible to know the structure and function of organisms never before discovered or that had not been possible to cultivate. For example, Fierer et al. (2012a) sequenced the metagenomes of samples from cold deserts, hot deserts, forests, grasslands and tundra. The desert communities had higher relative abundances of genes associated with osmoregulation and dormancy, but lower relative abundances of genes associated with nutrient cycling and the catabolism of plant-derived organic compounds. By studying the physiological mechanisms in which the products of these genes are involved, it will be possible to know how microbial communities can survive in environments with limited water and nutrients (Fierer et al. 2012b).

\section{Molecular plant nutrition}

Agricultural food production requires the application of fertilizers containing various nutrients, mainly $\mathrm{N}, \mathrm{P}$ and $\mathrm{K}$. The current availability of plant genome sequences and the development of molecular biology techniques have accelerated the identification of the assimilation pathways of these nutrients and the genes responsible for them. These advances have enabled biotech efforts to be focused on studying the regulation of these pathways and the interaction among them, to make more efficient use of these inputs and have a less negative impact on the environment. To date, 15 genomes of green algae and 185 of terrestrial plants have been completely sequenced or are in the process of being sequenced (http://www.ncbi.nlm.nih.gov/ genome/browse/). While many of these genomes are not yet complete, they have already proven to be a tool of great value to undertake breeding programs for agronomic traits such as fruit set, grain production and flowering time (Bolger et al. 2014). Figure 2 shows a summary of the genome sequencing of plants of agronomic interest and some model plants since the publication of the first complete genome of a higher plant, Arabidopsis thaliana, in
2000 (AGI 2000), to the last released of the cotton genome in May, 2015 ( $\mathrm{Li}$ et al. 2015). To date, sequence genomes of crop plants include rice (Oryza sativa), papaya (Carica papaya), maize (Zea mays), woodland strawberry (Fragaria vesca), tomato (Solanum lycopersicum), sugar beet (Beta vulgaris), Chinese cabbage (Brassica rapa), muskmelon (Cucumis melo), cucumber (Cucumis sativus), soybean (Glycine max), cocoa tree (Theobroma cacao), and apple (Malus domestica), among others (Schatz et al. 2012; Bolger et al. 2014).

Given the limited sources of fertilizers such as rock phosphate, a nonrenewable resource, and the general cost increases for these inputs, it is necessary to look for alternatives in the biodiversity of the soil itself. This could be achieved through microorganisms that take advantage of these nutrients and make them available to plants, or through the exploration of genotypes that efficiently use water and nutrients. In addition, the increase in sequenced crop plant genomes provides a huge reservoir of information that could be exploited to make better use of manures, fertilizers and bioinoculants. The genomes of the model plants Lotus japonicus (Sato et al. 2008) and Medicago truncatula ( $\mathrm{Li}$ et al. 2012), as well as of symbiotic microorganisms such as Rhizobium spp. (Servín-Garcidueñas et al. 2012), offer a window into the study and application of research on symbiotic interactions for more efficient use of fertilizer inputs and plant growth regulation. The following section discusses some of the most important advances concerning the metabolism of the major macronutrients, namely, $\mathrm{N}, \mathrm{P}$ and $\mathrm{K}$, on the basis of genomic and biochemical studies, as well as on microbially mediated plant nutrient transformations.

\section{Nitrogen $(\mathbf{N})$}

Plants can absorb and use various forms of $\mathrm{N}$ present in the soil, the most important being ammonium $\left(\mathrm{NH}_{4}{ }^{+}\right)$and nitrate $\left(\mathrm{NO}_{3}{ }^{-}\right)$, and in legumes, $\mathrm{N}$ can be obtained through symbiotic fixation processes. Some species show a strong preference for one ionic form over the other, although in sustainable agriculture it is necessary to look for an efficient use of these nitrogen sources and a balance between them (Wang et al. 2014a).

Plants have developed various mechanisms to regulate $\mathrm{N}$ metabolism in response to $\mathrm{N}$ availability and environmental conditions, and various enzymes are involved in the absorption, reduction, and assimilation of $\mathrm{N}$ sources. In higher plants, three families of transport proteins determine $\mathrm{NO}_{3}{ }^{-}$transport. The first family comprised of one of low affinity (LATS or low-affinity nitrate transport system), represented by the NRT1/PTR family of transporters that act in soils or culture media with high nitrate concentrations. The second and third families are composed of high 
Fig. 2 Genomes of model and agriculturally important plants sequenced or in the process of being sequenced according to NCBI (http://www.ncbi.nlm. nih.gov/genome/browse/). Column colors on the left of the DNA helix represent the underlying techniques and sequencing strategies used, while that on the right depicts the approximate timeline of when genomes were sequenced. The distinction between pure NGS and hybrid (Sanger +454/Illumina/SOLiD) sequencing is sometimes arbitrary, as many genome projects rely on previously generated Sanger sequences. $N G S$ next generation sequencing

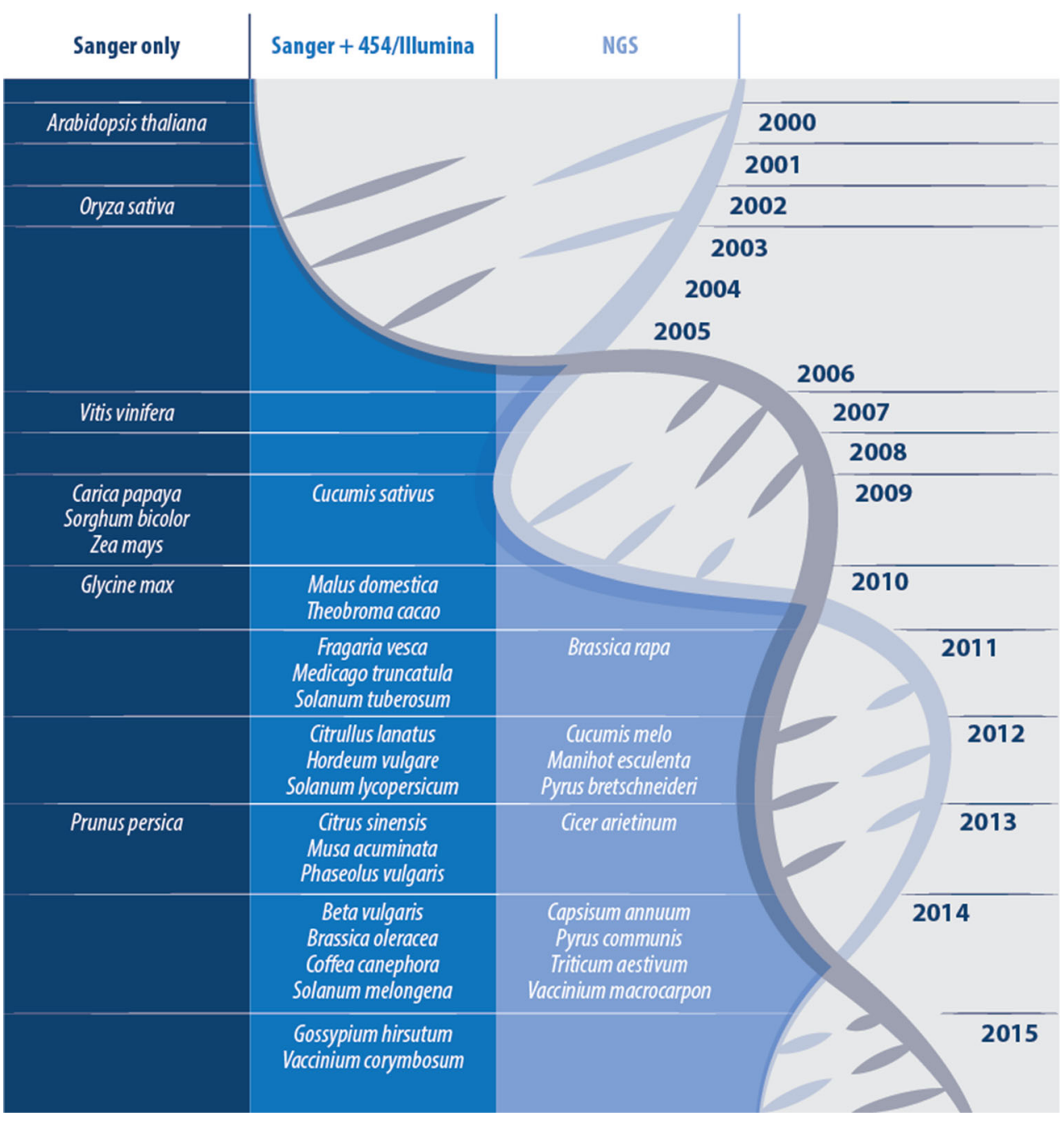

affinity (HATS or high-affinity nitrate transport system) constituted by the NRT2 and NRT3 (NAR) families of transporters which function when the available nitrate in the soil or growth medium is limited. The NRT1 family comprises 53 members, of which only nine have been characterized at the functional level and are predominantly low-affinity transporters; the NRT2 family contains seven members of high-affinity transporters; and there are two members of the NRT3 (NAR2) family involved in highaffinity transport (Krapp et al. 2014).

Regarding ammonium $\left(\mathrm{NH}_{4}{ }^{+}\right)$, its transporters are called AMT, and they are essential elements of the uptake pathway and homeostasis of $\mathrm{NH}_{4}{ }^{+}$in the root, since the uptake of this ion might cause toxicity, and it can be produced through other catabolic pathways in the cell. As ammonium homeostasis mechanisms, plant genomes contain several $A M T$ genes that encode for transporters that differ in their biochemical properties, location and in their regulation at the transcriptional level (Loqué and von Wirén 2004). In Arabidopsis thaliana, AMT genes make up a family of six members (two subfamilies) that transport $\mathrm{NH}_{4}{ }^{+}$in high-affinity systems (Krapp et al. 2014).

In a recent review, von Wittgenstein et al. (2014) highlighted that nitrogen uptake, reallocation within the plant, and between subcellular compartments involved ammonium, nitrate and peptide transporters. In angiosperms, each of the two families of $\mathrm{NH}_{4}{ }^{+}$transporters (AMT1 and AMT2) comprised of five members on average in angiosperms, while $\mathrm{NO}_{3}{ }^{-}$transporters also form two discrete families (NRT1 and NRT2), and angiosperm genomes encode only four NRT2s, on average. NRT1s share an evolutionary history with peptide transporters (PTRs). The NRT1/PTR family in land plants usually has more than 50 members and contains members with distinct activities, such as glucosinolate and abscisic acid transport. Identification and characterization of these gene families include the crop plants rice, sorghum, maize, soybean, papaya, cucumber, cassava, peach and grapevine.

Transcriptomic analyses of plant responses to nitrate have revealed a linkage between $\mathrm{N}$ and $\mathrm{S}$, and between $\mathrm{N}$ 
and Fe (Wang et al. 2003). Nitrate applications to N-deficient plants induce the expression of the nicotianamine synthase gene, which is involved in Fe uptake, transport and homeostasis in plants (Pich et al. 2001; García et al. 2010). Iron is required for the activity of many of the enzymes involved in the reduction and assimilation of nitrogen, including nitrate reductase, nitrite reductase and ferredoxin. Therefore, nitrate-induced nicotianamine synthesis probably occurs to facilitate Fe transport to support the synthesis of proteins for nitrate assimilation (OhkamaOhtsu and Wasaki 2010). The gene expression involved in hormone synthesis and perception is also affected by nitrate, and it has been demonstrated that this stimulates cytokinin biosynthesis (Takei et al. 2001). Two more hormones, auxins and abscisic acid, are involved in nitrateinduced lateral root growth inhibition (Liu et al. 2009).

Recent advances in the area of biofertilizers, specifically those related to symbiotic $\mathrm{N}$-fixing bacteria of the genus Rhizobium, and to free-living rhizobacteria of the genera Azospirillum, Azotobacter, Bacillus, Enterobacter, Pseudomonas, Serratia, and Streptomyces, show that it is possible to make efficient use of this resource without applying excessive concentrations of mineral fertilizers rich in $\mathrm{N}$ (Reddy 2014). In the case of arbuscular mycorrhizal (AM) fungi, specific ammonium transporters have been detected in the fungal mycelium, which enhance $\mathrm{N}$ uptake and use by the host plant (Pérez-Tienda et al. 2011, 2014).

Production and application of $\mathrm{N}$ fertilizers consume huge amounts of energy, and their excess use is detrimental to the environment. Improving $\mathrm{N}$ use efficiency (NUE) is therefore crucial, and represents a significant challenge for sustainable agriculture. For economically and environmentally friendly use of valuable $\mathrm{N}$ resources, developing high NUE cultivars is more challenging than targeting $\mathrm{N}$ applications as part of integrated nutrient management (FAO 2006). Complex multigene traits for NUE include the integration of genotypic and environmental conditions, particularly $\mathrm{N}$ supply. The proper evaluation of plant NUE to identify the main limiting factors for maximizing NUE has to be considered for crop improvement. The most important aspect of the different NUE components is the $\mathrm{N}$ requirement for producing the highest potential yield $(\mathrm{Xu}$ et al. 2012).

Even though $\mathrm{N}$ is the most studied macronutrient in plant metabolism, further studies are required of its uptake, transport and mobilization in plants. Identification and characterization of molecular mechanisms involved in such processes, as well as learning in greater detail the mechanisms used by soil microorganisms in the symbiotic fixation of this element and the exchange of cell signals in symbiotic relationships with host plants, remain to be elucidated (Santi et al. 2013; Yadav et al. 2015). Thanks to the most recent genomic and metagenomic projects, our understanding of the players and pathways of the global nitrogen cycle has advanced substantially over the last few years with discoveries of several new groups of organisms and new types of metabolism. Recently discovered processes add new functionality to the nitrogen cycle; these functions include denitrification and other dissimilatory nitrogen transformations in eukaryotes, anaerobic ammonium oxidation, and anaerobic methane oxidation with nitrite. The ecophysiology of the novel organisms and their interactions with classical types of nitrogen metabolism are important for understanding the nitrogen cycle and its tight links to the cycling of carbon, in the past, the present and the future (Thamdrup 2012).

\section{Phosphorus (P)}

Modern agriculture depends on the phosphorus supply that mostly comes from mined rock phosphate, which is a nonrenewable resource, and current global reserves may be depleted within a period of 50-100 years (Cordell and White 2011). While demand for this nutrient is projected to increase, peak production is predicted to occur before 2035, while the quality of rock phosphate ( $\mathrm{Pi}$ ) is decreasing and processing costs are rising (Cordell et al. 2009). It is therefore necessary to undertake strategies that make more efficient use of this resource, through sustainable technologies such as recycling and the use of P-solubilizing microorganisms.

Levels of $\mathrm{Pi}$ are suboptimal in most natural and agricultural ecosystems, and when $\mathrm{Pi}$ is applied as fertilizer in soils, it is rapidly immobilized owing to fixation and microbial activity (López-Arredondo et al. 2014). When Pi is supplied as fertilizer, it can be also immobilized due to its high reactivity with cations such as $\mathrm{Ca}$ and $\mathrm{Mg}$ in calcareous soils or $\mathrm{Al}$ and $\mathrm{Fe}$ in acidic soils. The abundance of soil microorganisms also affects Pi nutrition in a complex manner: while AM fungi and certain plant growth-promoting rhizobacteria may enhance plant $\mathrm{Pi}$ acquisition, many other microorganisms have adverse effects because of their competition with roots for Pi uptake and because their activities convert $\mathrm{Pi}$ into organic forms that are not readily available for plant uptake (Hinsinger 2001; Vance et al. 2003). Even under a well-designed Pi fertilization scheme, plant roots acquire no more than $30 \%$ of the applied Pi. This situation has led to the excessive application of fertilizers, contributing to the nutrient enrichment of water bodies that results in eutrophication and toxic algal blooms (Smith and Schindler 2009). Ironically, this phenomenon is leading to the extinction of hundreds of species. The unrestrained exploitation of rock phosphate, and our dependence on it for agriculture may lead to an unsafe situation in which Pi might become a commodity to be fought over, whilst at the same time, health and 
environmental experts are likely to recommend reductions in its use (Ferro et al. 2015).

Recent advances in our understanding of mechanisms by which wild and cultivated plant species adapt to lowphosphate conditions and the use of alternative bacterial pathways for $\mathrm{P}$ metabolism have resulted in the design of more effective breeding and genetic engineering strategies to produce highly Pi-efficient crops, optimize fertilizer use, and reach agricultural sustainability with a lower environmental cost (López-Arredondo et al. 2014). To develop low-Pi-tolerant crops, current research advances concerning the complex network of plant responses to Pi deficiency may allow the implementation of biotechnological strategies that take advantage of the genes involved in phosphate uptake, remobilization, and metabolism.

Plants acquire phosphorus from the soil solution as phosphate anion (Pi). It is the least mobile element in plants and soil, in comparison with other macronutrients. At the molecular level, the $\mathrm{Pi}$ ion is absorbed by the roots and translocated to other organs through phosphate transporters (PiT). To date, numerous proteins that encode PiT transporters in different species, including Arabidopsis, cereals, legumes and nightshades, have been found. The Arabidopsis genome contains 19 PiT genes clustered into four families: PHT1 to PHT4 (Wang et al. 2014b). The PHT1 family of proteins comprised of high-affinity $\mathrm{Pi} / \mathrm{H}^{+}$ symporters localized in the plasma membrane and their main function is to acquire $\mathrm{Pi}$ from the rhizosphere since most of them are expressed in the epidermis of root cells, whereas the other PHT families are located in other endomembrane systems. For example, PHT2 transporters are only localized in chloroplasts (Versaw and Harrison 2002), PHT3 ones in mitochondria (Poirier and Bucher 2002), and PHT4 members in non-photosynthetic plastids and in the Golgi apparatus (Guo et al. 2008). In addition to $\mathrm{Pi}$, PiT transporters can absorb phosphite (Phi), an analog of Pi. Although the uptake and mobility of Phi and Pi are similar, there is no evidence showing that plants can utilize Phi as their sole source of phosphorus. Furthermore, it has been demonstrated that Phi interferes in many plant responses to Pi deficiency. For example, Phi inhibits root growth and the root/shoot ratio in Pi-deficient media but not in sufficient conditions of this ion. Interestingly, Estrada-Ortiz et al. (2013) showed that adding Phi to the nutrient solution used for growing strawberries improves some fruit quality characteristics when there is sufficient $\mathrm{Pi}$, and it has been postulated that Phi could activate defense mechanisms against pathogen attack. In fact, Oyarburo et al. (2015) recommend the use of Phi as an agent to activate defense, cellular signal transduction and quality improvement mechanisms in certain conditions and for certain crops. The only way that plants can use Phi as a $\mathrm{P}$-source is through the expression of a bacterial phosphite dehydrogenase, as has been reported for Arabidopsis thaliana and Nicotiana tabacum (López-Arredondo and Herrera-Estrella 2012), which opens up new opportunities to use Phi as a $\mathrm{P}$-source in $\mathrm{P}$ nutrition approaches.

Phosphate is precipitated as orthophosphate or adsorbed by $\mathrm{Fe}$ and $\mathrm{Al}$ in acid soils or by $\mathrm{Ca}$ or $\mathrm{Mg}$ in basic soils (Vance 2001; López-Arredondo et al. 2014). Phosphorussolubilizing bacteria play a very important role in phosphate nutrition by enhancing its availability to plants through the release of this element from organic and inorganic soils (Mohammadi 2012). The main mechanism that exists in soil to solubilize phosphate is through lowering the $\mathrm{pH}$ by the production of organic acids by microorganisms and mineralization of organic $\mathrm{P}$ by means of acid phosphatase enzymes. The use of P-solubilizing bacteria as inoculants increases $\mathrm{P}$ uptake from the soil. These bacteria also enable the use of rock phosphate for crop production (Nobandegani et al. 2015). In this regard, Singh and Satyanarayana (2011) reviewed the importance of phytases and the microorganisms that produce them, in the use of organic phytate sources. Among the most promising P-solubilizing microorganisms are bacterial strains of the genera Pseudomonas, Bacillus and Rhizobium and fungi of the genera Galactomyces and Penicillium. According to Zaidi et al. (2009), among the diverse and abundant microbes inhabiting the rhizosphere, those that possess the ability to solubilize phosphate represent an alternative biotechnological solution in sustainable agriculture to meet the $\mathrm{P}$ demands of plants. Through conventional methodologies for morphological and functional characterization of microorganisms and analysis of $18 \mathrm{~S}$ rRNA gene sequences, Wu et al. (2012a) isolated the fungus Galactomyces geotrichum strain P14 (P14), which showed ample ability to release phosphate and solubilize rock phosphate, implying great potential for use as a biofertilizer to enhance soil fertility and promote plant growth. Subsequently, Chai et al. (2011) isolated a fungus identified as Penicillium sp. strain PSM11-5, which showed high phosphate-solubilizing ability in media with $\mathrm{pH}$ values ranging from 5.0 to 8.0. Vassileva et al. (2010) observed that a single phosphate-solubilizing organism can show a wide range of metabolic abilities in different environments. When grown in bioreactors, these organisms can produce several types of enzymes, siderophores and plant growth regulators. The introduction of these biotech products in the soil-plant system improves plant growth, soil properties, soil biological activity, and plant defense mechanisms.

Another biological mechanism is represented by mycorrhizal symbiosis. In this mechanism, the establishment of AM fungi in the root of a host plant results in the promotion of plant growth by direct effect of improving the uptake and utilization of essential nutrients in plant 
metabolism (Chen et al. 2013; Ouziad et al. 2006; PérezTienda et al. 2011, 2014).

Various research groups worldwide have analyzed global changes in plants in response to $\mathrm{P}$, either through transcriptomic studies (Wasaki et al. 2006), metabolomic studies (Huang et al. 2008) or integrated ones [transcriptomics, proteomics and metabolomics; (Morcuende et al. 2007)]. Phosphorus deficiency quickly causes the induction of high-affinity $\mathrm{P}$ transporters and acidic phosphatases, as well as glycolysis, possibly as a mechanism to produce organic acids which allow the recycling of $\mathrm{P}$ from phosphorylated intermediate compounds. Unlike the general repression of amino acid synthesis caused by $\mathrm{N}$ deficiency, $\mathrm{P}$ deficiency only induces aromatic amino acid synthesis, but represses the synthesis of nucleic acids and proteins and the gene expression involved in photosynthesis (Ohkama-Ohtsu and Wasaki 2010). Mission et al. (2005) also demonstrated the interaction between $\mathrm{P}$ and $\mathrm{Fe}$. It has thus been possible to detect genes encoding phosphate transporters in plants that establish symbiosis with AM fungi (Chen et al. 2013; Ouziad et al. 2006).

Recently, Becquer et al. (2014) described the journey of $\mathrm{P}$ from the soil to the plant through trophic relationships and ectomycorrhizal association to understand the ecological and molecular mechanisms responsible for transferring Pi and improving plant $\mathrm{P}$ nutrition. Ectomycorrhizal fungi improve nutrient status of plants, as they are able to release organic anions or phosphatases to mobilize unavailable P (Louche et al. 2010; Plassard and Dell 2010). Furthermore, bacteria play a major role in the mineralization of $\mathrm{P}$ through trophic relationships as they can produce phytases to degrade phytate, the main form of soil organic P. Bacteria are also more effective than other microorganisms or plants at immobilizing free Pi. Interestingly, free Pi may be taken up by ectomycorrhizal fungi by specific phosphate transporters and transferred to the plant by mechanisms not yet been identified (Becquer et al. 2014).

Despite the numerous studies that have been conducted on these microorganisms and their multifunctional properties, the development of commercial bioinoculants is still far from realization. In fact, direct inoculation of free phosphate-solubilizing bacteria (PSB) into soil does not easily maintain cell survival around plants roots because they are susceptible to a variety of environmental variations (Wu et al. 2012b). Variability in the effect of PSB inoculants applied to crops is largely due to the relative effectiveness of the bacterial strain in the inoculant formulation, which can determine the success or failure of a biological agent.

Interestingly, immobilization of bacterial cells has been widely used in agriculture to achieve a protective structure or capsule allowing immobilization, protection, release and functionalization of active ingredients (Schoebitz et al. 2013). Therefore, current progress in studies exploring functional diversity, the ability to colonize the rhizosphere, mode of action and applications in agriculture and industry may facilitate their use as reliable components in sustainable agricultural systems of the future.

\section{Potassium (K)}

Over $90 \%$ of potassium in soil exists in the form of silicate minerals (microcline, muscovite, orthoclase biotite and feldspars, among others) (Meena et al. 2014). These minerals can be weathered through protonation processes but also form complexes with organic acids, and it has been shown that some acidic polysaccharides of microbial origin may also have some role in these processes (Ehrlich 2002).

The average $\mathrm{K}$ reserves in soil are abundant, although most of it is not available to the plant. Therefore, crops have to be supplied with soluble $\mathrm{K}$ and the demand for it is increasing every year. Organic exudates of some bacteria and plant roots play a key role in the release of $\mathrm{K}$ contained in minerals, which is why the search for genotypes that show better mechanisms for accessing the $\mathrm{K}$ contained in these rock materials is one of the main breeding approaches in sustainable agriculture. Potassium deficiency affects the flow of photosynthates to sink organs, which causes sugars to build up in the leaf and they, in turn, reduce yields and crop quality. Because of its pivotal role in turgor, primary metabolite generation and long-distance transport processes, $\mathrm{K}$ is a key component in mechanisms providing tolerance to drought, salinity, high brightness and cold, as well as to pathogens and pest insects. Despite its importance in these and other vital processes, there has not been strong interest in breeding to increase uptake and efficient use of this element, which requires rethinking the study objectives of various working groups in the world and prioritizing research on $\mathrm{K}$ as a key macronutrient in soil fertility and food security (Zörb et al. 2014).

In plants, $\mathrm{K}$ membrane transport is mediated by $\mathrm{K}$ channels and second by $\mathrm{K}$ transporters (Gierth and Mäser 2007). In the model plant Arabidopsis thaliana, there are five families of genes involved in uptake, transport and mobilization of $\mathrm{K}$ from the soil to the fruit and within the plant itself: two families of different channels ( 15 genes); two families of transporters (14 genes) and a family of antiporters (six genes). $\mathrm{K}^{+}$channels are by far the best characterized enzymes in terms of regulation of ionic input and output, second messengers and transport (Sharma et al. 2013). However, little is known about permease-type transporters and antiporters (Gómez-Porras et al. 2012). Recently, Véry et al. (2014) performed a comparison of some of these family systems between species, including Arabidopsis, rice and grapevine, giving insights into the 
structure of their members and on functional properties and their roles in $\mathrm{K}$ metabolism.

In plants, $\mathrm{K}$ deficiencies facilitate the entry and spread of pathogens and insects (Amtmann et al. 2008). Microarray experiments revealed strong repression of $\mathrm{N}$ transporters in K-deficient plants, which is quickly counteracted to supply sufficient $\mathrm{K}$ to the plants. Crop yield in conditions of $\mathrm{K}$ deficiency and attack by pathogens and insects is differentially affected by the degree of synergistic and antagonistic effects which occur in the plant in response to this kind of stress (Armengaud et al. 2004), and it has been discovered that some symbiotic organisms can contribute to potassium buildup in certain host plants (Basak and Biswas 2010).

Some species of microorganisms, including Pseudomonas spp., Burkholderia spp., Acidithiobacillus ferrooxidans, Bacillus mucilaginosus, Bacillus edaphicus and Bacillus megaterium, have the ability to release $\mathrm{K}$ from materials containing this element by exudation of organic acids (Zörb et al. 2014). These acids directly dissolve the $\mathrm{K}$ contained in rock minerals or chelate the primary ions contained in the minerals to release $\mathrm{K}$ (Basak and Biswas 2009). As a result, inoculation with K-solubilizing microorganisms together with the application of minerals rich in $\mathrm{K}$ are strategies that are receiving great interest worldwide, as evidenced by the work of Sheng (2005), Han et al. (2006) and Meena et al. (2014) in different crop plants. Exudates produced by these organisms can increase the release of potassium from clay minerals and $\mathrm{K}$ solubility by up to $60 \%$ (Han et al. 2006; Basak and Biswas 2009; Abou-el-Seoud and Abdel-Megeed 2012). El-Hadad et al. (2011) reported that biofertilizers formulated with Paenibacillus polymyxa (N-fixing bacteria), Bacillus megaterium (P-solubilizing bacteria), and Bacillus circulans (K-solubilizing bacteria) have nematicidal activity against Meloidogyne incognita, demonstrating that these bacteria not only participate in the mobilization of the major macronutrients ( $\mathrm{N}, \mathrm{P}$ and $\mathrm{K}$ ), but are also involved in the biological control of nematodes such as $M$. incognita. However, there is a need for more field studies, because what has been done until now has only been carried out in laboratory and greenhouse conditions.

Meena et al. (2014) highlighted the pivotal role played by potassium-solubilizing microorganisms (KSM) in $\mathrm{K}$ plant nutrition. A large number of saprophytic bacteria (including Bacillus mucilaginosus, Bacillus edaphicus, Bacillus circulans, Acidothiobacillus ferrooxidans, and Paenibacillus spp.) and fungal strains (Aspergillus spp. and Aspergillus terreus) mediate K-solubilization in soil system. The main mechanisms of KSM are acidolysis, chelation, exchange reactions, complexolysis and production of organic acid. Once $\mathrm{K}$ has been solubilized by KSM, the plant can easily take it up for growth and development.
Here, one of the major challenges to support sustainable agriculture is to identify and characterize indigenous K-solubilizing microbes to develop efficient microbial consortia for solubilization of $\mathrm{K}$ in soil, thus enhancing plant growth and crop yields.

Just recently, on the basis of $16 \mathrm{~S}$ ribosomal DNA (16S rDNA) sequencing, Meena et al. (2015) identified $12 \mathrm{~K}$ solubilizing rhizobacteria (KSR). Among the assessed 12 KSR, A. tumefaciens OPVS 11 and $R$. pusense OPVS6 occurred at the highest K-solubilizing frequency. These strains demonstrated significant reduction in media $\mathrm{pH}$ and increased $\mathrm{K}$ release with incubation period under both waste muscovite and biotite as a sole source of insoluble $\mathrm{K}$ mineral.

\section{Scope and limitations of genomic approaches}

It was about 15 years ago that the first genome sequencing of a higher plant, Arabidopsis thaliana, was completed, and about 13 years ago that the sequenced genome of a crop plant, rice, was published. From that time on, the number of sequenced genomes of crop plants has grown steadily. At present, $63 \%$ of the sequenced plant genomes belong to crop species (Michael and VanBuren 2015). The rate at which these genomes are being made publicly available is due to the improvement in sequencing technologies, both in terms of time and cost. Modern technologies allow sequencing of multiple genotypes of a crop at a reasonable cost. Although most of the published genomes are not complete, the data they provide are very valuable for understanding important agronomic traits such as fruit set, grain production, and flowering times.

Genomic tools have enormous potential to expand the applications of the metabolic capabilities of microorganisms in plant nutrition strategies, as well as to determine in greater detail the mechanisms that plants have for better nutrient utilization. Although most are still costly, these tools can stimulate the development of innovative technologies for plant nutrition. While some of these technologies are still under development and need to be optimized, their application in certain areas has already proven to be successful, which has led to greater scientific and industrial interest in the identification of key molecules, metabolic pathways and applications in crop nutrition.

In contrast to the tremendous advances in throughput, assembling sequencing reads remains a substantial endeavor, much greater than the sequencing efforts alone would suggest (Salzberg et al. 2012). Large complex plant genomes remain a particularly difficult challenge for de novo assembly for a variety of biological, computational and biomolecular reasons addressed by Schatz et al. (2012). 
Therefore, a general interdisciplinary effort must be made to develop efficient technologies to assemble these genomes accurately, make better use of the potentially highly fragmented assemblies and perform these applications at the lowest cost.

The emergence of metagenomics has the potential to revolutionize plant nutrition since it provides direct access to microbial communities that inhabit environments (optimal or limiting), in their entire complexity and regardless of the feasibility of being cultivated. Isolation and characterization of functional genes as well as sequencing of complete metagenomes have the potential to lead to the discovery of new metabolic activities and generate valuable information for the best use of manures and fertilizers under a sustainable development perspective.

Nevertheless, many of the available metagenomic techniques and protocols have their own limitations ( $\mathrm{Ra}-$ jendhran and Gunasekaran 2008). One of the constraints on these methods is the complexity of the sample per se and the pollutants present in it, including humus, organic contaminants and heavy metals, among others, that impede its processing (Rajesh et al. 2012). Another common obstacle is the lysis of the full sample and the removal of substances that interfere with DNA extraction (Dua et al. 2002). Lack of knowledge of local and global diversity of microbial communities and populations with symbiotic ability with cultivated plants is also a limitation. In addition, there is little exchange of information and standards among microbial ecology laboratories to enable comparative analyses.

Functional analyses of environmental genomic libraries are not designed to identify genes involved in uptake, transport, and nutrient metabolism processes (Mirete et al. 2007; Guazzaroni et al. 2013). While these functions could be studied using microarrays, the nature of the samples and the limited availability of universal controls impose further complications for understanding the intensity of the detected signals and their correlation with specific species. Furthermore, microarray-based analysis is only qualitative because it only detects the presence or absence of a particular microbial group.

Other methodologies involving gold nanoparticles, quantum dots and magnetic particles are being introduced to the market and offer promising strategies for in situ analysis of microbial communities. However, to date, none of them has been optimized to make direct specific measurements in the environment (Rincon-Florez et al. 2013).

Despite the enormous progress made, metagenomic approaches cannot yet be widely applied in plant nutrition, and the tools used have achieved few concrete results. One of the reasons that may explain this is the fact that functional analyses of metagenomic libraries are limited by the lack of appropriate analysis tools and the insufficiency of available host systems. Nor are there any reports of obligate or facultative anaerobic hosts being used for analyzing metagenomes in oxygen-deprived conditions, which represents one of the major challenges given the importance of microbial metabolic processes in anoxic conditions. Hence, one of the most pressing priorities is to develop host and expression systems in these oxygen-deprived conditions. Furthermore, large-scale genome sequencing projects in agricultural environments and analysis of the information collected take years, thereby delaying efforts to apply the information generated in crop nutrition initiatives.

One of the major challenges to come involves the amount of data generated through metagenomic projects. Deposits of microorganism sequences are increasing every year, and they are expected to grow exponentially as sequencing technologies improve. However, massive sequencing alone is not capable of defining specific metabolic functions, so it must be coupled to advances in basic microbiology, biochemistry, functional genomics and bioinformatics. New computational tools to be generated in the future will enable defining the functions of new proteins discovered in metagenomic efforts, which may benefit plant nutrition approaches that are being developed.

The good news is that there is growing interest in carrying out more in-depth analyses. For example, Edwards et al. (2013) demonstrated that new generations of life scientists are able to develop strategies to generate and take advantage of information in the new era of sequencing and genomic sciences.

The genomic sciences are faced with two additional challenges, which are partially opposed. On the one hand, the dynamics of microbial communities in response to stressful environments is complex, and the biodiversity in oligotrophic environments such as soils, as well as the number of new genes, is much greater than first predicted. However, metagenomic data only give a partial picture of this diversity and the contribution of particular low-abundant taxa is not reliable. The isolation of individual cells and their sequencing could provide more information about the biological processes that take place in microbial cells that develop in these environments (Lasken 2012).

Together with deep phenotyping platforms, which promise to overcome some technical bottlenecks, we can expect an even faster elucidation of numerous gene functions, but we will be challenged by the sheer magnitude of data available.

Beyond the current advances in plant genomics and microbial metagenomics, the advent of next generation sequencing (NGS) technology has resulted in an urgent need for novel tools to analyze those high-throughput datasets, as well as for young scientists able to develop new computer and engineering strategies to take advantage of changing whole genome and metagenome analyses. 
Progress in the field of NGS and omics, beyond the classical genomics, transcriptomics, proteomics and metabolomics, has led to the establishment of new molecular concepts such as exomics (Franzosa et al. 2015; Kahl 2015; Kawalia et al. 2015). Exome sequencing represents a significant tool for assessing natural evolution in plants, identifying gene pools involved in symbiotic and other coexistential systems, and improving crop production, as exons assist in interpretation of allelic variation with respect to their phenotype (Hashmi et al. 2015). These technologies are used in exploring the biodiversity of crops, thereby providing better understanding of genomic resources for crop wild relatives so that they can be used in breeding, allele identification and introgression. Draft genomes from wild relatives of some crop species are currently available, but more wild species are needed for crop improvement programs (Michael and VanBuren 2015)

These issues represent major challenges for the genomic sciences that will have to be addressed under interdisciplinary approaches in the future.

\section{Conclusions}

Soil science has advanced greatly thanks to the progress made by molecular biology, especially genome sequencing, to understand and characterize this complex system, both at the level of microorganisms that inhabit it and the plants that thrive on it. This has enabled the development of new fields of knowledge such as metagenomics, molecular microbiology and molecular plant nutrition. It has thus been possible to learn in detail how microorganisms intervene in plant nutrition and growth, and how they absorb, transport and take advantage of nutrients. The challenge for the sustainability of agriculture and food security lies in effectively utilizing soil biodiversity through better knowledge of the organisms that inhabit this complex system. In addition, plant mechanisms that determine better use of these inputs need to be further investigated, especially since some mineral fertilizer sources on the planet are prone to run out, become increasingly expensive, and negatively impact the environment. Molecular biology and metagenomics are tools that are enabling us to understand these soil resources and to find the best way to take advantage of them for the development of new plant nutrition approaches.

While some genomic and metagenomic disciplines are in development, all of them have the potential to generate unprecedented information on the nature, regulation and evolution of metabolic pathways of plant-microorganism interactions that take place in different environments. This information constitutes the first step towards implementing effective strategies for efficient nutrient use by plants, and thus these approaches are emerging as solid pillars of research for the years to come. Additionally, a growing need can be seen for scientists with the ability to analyze, interpret and apply this knowledge under biotechnological innovation approaches.

Author contribution statement Authors contributed equally to the paper.

Acknowledgments The Colegio de Postgraduados Priority Research Line No. 5 in Microbial, Plant and Animal Biotechnology supported this work. The authors are very thankful to the Line of Generation and Application of Knowledge No. 1 from the Agri-food Sustainable Innovation MSc Program from the Colegio de Postgraduados Campus Córdoba (Mexico).

\section{Compliance with ethical standards}

Conflict of interest The authors declare that they have no conflict of interest.

Open Access This article is distributed under the terms of the Creative Commons Attribution 4.0 International License (http://crea tivecommons.org/licenses/by/4.0/), which permits unrestricted use, distribution, and reproduction in any medium, provided you give appropriate credit to the original author(s) and the source, provide a link to the Creative Commons license, and indicate if changes were made.

\section{References}

Abou-El-Seoud II, Abdel-Megeed A (2012) Impact of rock materials and biofertilizations on $\mathrm{P}$ and $\mathrm{K}$ availability for maize (Zea mays) under calcareous soil conditions. Saudi J Biol Sci 19:55-63. doi:10.1016/j.sjbs.2011.09.001

Adam G, Duncan H (2001) Development of a sensitive and rapid method for the measurement of total microbial activity using fluorescein diacetate (FDA) in a range of soils. Soil Biol Biochem 33:943-951. doi:10.1016/S0038-0717(00)00244-3

AGI (2000) Analysis of the genome sequence of the flowering plant Arabidopsis thaliana. Nature 408:796-815. doi:10.1038/ 35048692

Alarcón A, Hernández-Cuevas LV, Ferrera-Cerrato R, FrancoRamírez A (2012) Diversity and agricultural applications of arbuscular mycorrhizal fungi in Mexico. J Biofertil Biopestici 3:115. doi:10.4172/2155-6202.1000115

Alessi DS, Walsh DM, Fein JB (2011) Uncertainties in determining microbial biomass $\mathrm{C}$ using the chloroform fumigation-extraction method. Chem Geol 280:58-64. doi:10.1016/j.chemgeo.2010.10. 014

Amtmann A, Troufflard S, Armengaud P (2008) The effect of potassium nutrition on pest and disease resistance in plants. Physiol Plant 133:682-691. doi:10.1111/j.1399-3054.2008. 01075

Armengaud P, Breitling R, Amtmann A (2004) The potassiumdependent transcriptome of Arabidopsis reveals a prominent role of jasmonic acid in nutrient signaling. Plant Physiol 136:2556-2576. doi:10.1104/pp.104.046482

Badri DV, Weir TL, van der Lelie D, Vivanco JM (2009) Rhizosphere chemical dialogues: plant-microbe interactions. Curr Opin Biotechnol 20:642-650. doi:10.1016/j.copbio.2009.09.014 
Bakker MG, Schlatter DC, Otto-Hanson L, Kinkel LL (2014) Diffuse symbioses: roles of plant-plant, plant-microbe and microbemicrobe interactions in structuring the soil microbiome. Mol Ecol 23:1571-1583. doi:10.1111/mec.12571

Basak BB, Biswas DR (2009) Influence of potassium solubilizing microorganism (Bacillus mucilaginosus) and waste mica on potassium uptake dynamics by sudan grass (Sorghum vulgare Pers.) grown under two Alfisols. Plant Soil 317:235-255. doi:10. 1007/s11104-008-9805-Z

Basak BB, Biswas DR (2010) Co-inoculation of potassium solubilizing and nitrogen fixing bacteria on solubilization of waste mica and their effect on growth promotion and nutrient acquisition by a forage crop. Biol Fertil Soil 46:641-648. doi:10.1007/s00374-010-0456-x

Bastida F, Hernández T, Albaladejo J, García C (2013) Phylogenetic and functional changes in the microbial community of long-term restored soils under semiarid climate. Soil Biol Biochem 65:12-21. doi:10.1016/j.soilbio.2013.04.022

Becquer A, Trap J, Irshad U, Ali MA, Claude P (2014) From soil to plant, the journey of $\mathrm{P}$ through trophic relationships and ectomycorrhizal association. Front Plant Sci 5:548. doi:10. 3389/fpls.2014.00548

Bolger ME, Weisshaar B, Scholz U, Stein N, Usadel B, Mayer KF (2014) Plant genome sequencing-applications for crop improvement. Curr Opin Biotechnol 26:31-37. doi:10.1016/j. copbio.2013.08.019

Chai B, Wu Y, Liu P, Liu B, Gao M (2011) Isolation and phosphatesolubilizing ability of a fungus, Penicillium sp. from soil of an alum mine. J Basic Microbiol 51:5-14. doi:10.1002/jobm. 201000192

Chang HW, Sung Y, Kim KH, Nam YD, Roh SW, Kim MS, Jeon CO, Bae JW (2008) Development of microbial genome-probing microarrays using digital multiple displacement amplification of uncultivated microbial single cells. Environ Sci Technol 42:6058-6064. doi:10.1021/es8006029

Chen XW, Wu FY, Li H, Chan WF, Wu C, Wu SC, Wong MH (2013) Phosphate transporters expression in rice (Oryza sativa L.) associated with arbuscular mycorrhizal fungi (AMF) colonization under different levels of arsenate stress. Environ Exp Bot 87:92-99. doi:10.1016/j.envexpbot.2012.08.002

Cleary DFR, Smalla K, Mendonça-Hagler LCS, Gomes NCM (2012) Assessment of variation in bacterial composition among microhabitats in a mangrove environment using DGGE fingerprints and barcoded pyrosequencing. PLoS One 7:e29380. doi:10.1371/ journal.pone.0029380

Cordell D, White S (2011) Peak phosphorus: clarifying the key issues of a vigorous debate about long-term phosphorus security. Sustainability 3:2027-2049. doi:10.3390/su3102027

Cordell D, Drangert JO, White S (2009) The story of phosphorus: global food security and food for thought. Glob Environ Change 19:292-305. doi:10.1016/j.gloenvcha.2008.10.009

Cordell D, Rosemarin A, Schröder JJ, Smit AL (2011) Towards global phosphorus security: a systems framework for phosphorus recovery and reuse options. Chemosphere 84:747-758. doi:10. 1016/j.chemosphere.2011.02.032

Davinic M, Fultz LM, Acosta-Martinez V, Calderón FJ, Cox SB, Dowd SE, Allen VG, Zak JC, Moore-Kucera J (2012) Pyrosequencing and mid-infrared spectroscopy reveal distinct aggregate stratification of soil bacterial communities and organic matter composition. Soil Biol Biochem 46:63-72. doi:10.1016/j. soilbio.2011.11.012

Dowd SE, Sun Y, Secor PR, Rhoads DD, Wolcott BM, James GA, Wolcott RD (2008) Survey of bacterial diversity in chronic wounds using pyrosequencing, DGGE, and full ribosome shotgun sequencing. BMC Microbiol 8:43. doi:10.1186/1471$2180-8-43$
Dua M, Singh A, Sethunathan N, Johri AK (2002) Biotechnology and bioremediation: successes and limitations. Appl Microbiol Biotechnol 59:143-152. doi:10.1007/s00253-002-1024-6

Dumont MG, Murrell JC (2005) Stable isotope probing-linking microbial identity to function. Nat Rev Microbiol 3:499-504. doi:10.1038/nrmicro1162

Edwards RA, Haggerty JM, Cassman N, Busch JC, Aguinaldo K, Chinta S, Vaughn MH, Morey R, Harkins TT, Teiling C, Fredrikson K, Dinsdale EA (2013) Microbes, metagenomes and marine mammals: enabling the next generation of scientist to enter the genomic era. BMC Genom 14:600. doi:10.1186/14712164-14-600

Egan AN, Schlueter J, Spooner DM (2012) Applications of nextgeneration sequencing in plant biology. Am J Bot 99:175-185. doi:10.3732/ajb.1200020

Ehrlich H (2002) Interactions between microorganisms and minerals under anaerobic conditions. In: Huang PM, Bollag JM, Senesi N (eds) Interactions between soil particles and microorganisms. Wiley, New York, pp 459-494

El-Hadad ME, Mustafa MI, Selim ShM, El-Tayeb TS, Mahgoob AE, Abdel Aziz NH (2011) The nematicidal effect of some bacterial biofertilizers on Meloidogyne incognita in sandy soil. Braz $\mathrm{J}$ Microbiol 42:105-113. doi:10.1590/S1517-83822011000100014

Estrada-Ortiz E, Trejo-Téllez LI, Gómez-Me-rino FC, Núñez-Escobar R, Sandoval-Villa M (2013) The effects of phosphite on strawberry yield and fruit quality. J Soil Sci Plant Nutr 13:612-620. doi:10.4067/S0718-95162013005000049

FAO (2006) Plant nutrition for food security. A guide for integrated nutrient management. FAO Fertilizer and Plant Nutrition Bulletin No. 16. Food and Agriculture Organization of the United Nations. Rome, Italy. ftp://fao.org/docrep/fao/009/ a0443e/a0443e.pdf. Accessed 10 June 2015

Ferro CJ, Ritz E, Townend JN (2015) Phosphate: are we squandering a scarce commodity? Nephrol Dial Transplant 30:163-168. doi:10.1093/ndt/gfu295

Fierer N, Breitbart M, Nulton J, Salamon P, Lozupone C, Jones R, Robeson M, Edwards RA, Felts B, Rayhawk S, Knight R, Rohwer F, Jackson RB (2007) Metagenomic and small-subunit rRNA analyses reveal the genetic diversity of bacteria, archaea, fungi, and viruses in soil. Appl Environ Microbiol 73:7059-7066. doi:10.1128/AEM.00358-07

Fierer N, Leff JW, Adams BJ, Nielsen UN, Bates ST, Lauber CL, Owens S, Gilbert JA, Wall DH, Caporaso JG (2012a) Crossbiome metagenomic analyses of soil microbial communities and their functional attributes. Proc Natl Acad Sci USA 109:21390-21395. doi:10.1073/pnas.1215210110

Fierer N, Lauber CL, Ramirez KS, Zaneveld J, Bradford MA, Knight R (2012b) Comparative metagenomic, phylogenetic and physiological analyses of soil microbial communities across nitrogen gradients. ISME J 6:1007-1017. doi:10.1038/ismej.2011.159

Franzosa EA, Hsu T, Sirota-Madi A, Shafquat A, Abu-Ali G, Morgan XC, Huttenhower C (2015) Sequencing and beyond: integrating molecular 'omics' for microbial community profiling. Nat Rev Microbiol 13:360-372. doi:10.1038/nrmicro3451

Fritsch P, Rieseberg LH (1996) The use of random amplified polymorphic DNA (RAPD) in conservation genetics. In: Smith TB, Wayne RK (eds) Molecular genetics approaches in conservation. Oxford University Press, Oxford, pp 54-73

García MJ, Lucena C, Romera FJ, Alcántara E, Pérez-Vicente R (2010) Ethylene and nitric oxide involvement in the upregulation of key genes related to iron acquisition and homeostasis in Arabidopsis. J Exp Bot 61:3885-3899. doi:10.1093/ jxb/erq203

Gierth M, Mäser P (2007) Potassium transporters in plantsinvolvement in $\mathrm{K}^{+}$acquisition, redistribution and homeostasis. FEBS Lett 581:2348-2356. doi:10.1016/j.febslet.2007.03.035 
Gómez-Porras JL, Riaño-Pachón DM, Benito B, Haro R, Sklodowski K, Rodríguez-Navarro A, Dreyer I (2012) Phylogenetic analysis of $\mathrm{K}^{+}$transporters in bryophytes, lycophytes, and flowering plants indicates a specialization of vascular plants. Front Plant Sci 3:167. doi:10.3389/fpls.2012.00167

Green V, Stott D, Diack M (2006) Assay for fluorescein diacetate hydrolytic activity: optimization for soil samples. Soil Biol Biochem 38:693-701. doi:10.1016/j.soilbio.2005.06.020

Guazzaroni ME, Morgante V, Mirete S, González-Pastor JE (2013) Novel acid resistance genes from the metagenome of the Tinto River, an extremely acidic environment. Environ Microbiol 15:1088-1102. doi:10.1111/1462-2920.12021

Guo B, Jin Y, Wussler C, Blancaflor EB, Motes CM, Versaw WK (2008) Functional analysis of the Arabidopsis PHT4 family of intracellular phosphate transporters. New Phytol 177:889-898. doi:10.1111/j.1469-8137.2007.02331.x

Han HS, Supanjani, Lee KD (2006) Effect of co-inoculation with phosphate and potassium solubilizing bacteria on mineral uptake and growth of pepper and cucumber. Plant Soil Environ 52:130-136

Hashmi U, Shafqat S, Khan F, Majid M, Hussain H, Kazi AG, John R, Ahmad P (2015) Plant exomics: concepts, applications and methodologies in crop improvement. Plant Signal Behav 10:e976152. doi:10.4161/15592324.2014.976152

He Z, Deng Y, Zhou J (2012) Development of functional gene microarrays for microbial community analysis. Curr Opin Biotechnol 23:49-55. doi:10.1016/j.copbio.2011.11.001

Hinsinger P (2001) Bioavailability of soil inorganic P in the rhizosphere as affected by root-induced chemical changes: a review. Plant Soil 237:173-181. doi:10.1023/A:1013351617532

Huang CY, Roessner U, Eickmeier I, Genc Y, Callahan DL, Shirley N, Langridge P, Bacic A (2008) Metabolite profiling reveals distinct changes in carbon and nitrogen metabolism in phosphate-deficient barley plants (Hordeum vulgare L.). Plant Cell Physiol 49:691-703. doi:10.1093/pcp/pcn044

Insam H (2001) Developments in soil microbiology since the mid 1960s. Geoderma 100:389-402. doi:10.1016/S00167061(01)00029-5

Kahl G (2015) The dictionary of genomics, transcriptomics and proteomics. Wiley-VCH, Weinheim 2742 p

Kakavas VK, Plageras P, Vlachos TA, Papaioannou A, Noulas VA (2008) PCR-SSCP: a method for the molecular analysis of genetic diseases. Mol Biotechnol 38:155-163. doi:10.1007/ s12033-007-9006-7

Kawalia A, Motameny S, Wonczak S, Thiele H, Nieroda L, Jabbari K, Borowski S, Sinha V, Gunia W, Lang U, Achter V, Nürnberg $\mathrm{P}$ (2015) Leveraging the power of high performance computing for next generation sequencing data analysis: tricks and twists from a high throughput exome workflow. PLoS One 10:e0126321. doi:10.1371/journal.pone.0126321

Kirk JL, Beaudette LA, Hart M, Moutoglis P, Klironomos JN, Lee H, Trevors JT (2004) Methods of studying soil microbial diversity. J Microbiol Methods 58:169-188. doi:10.1016/j.mimet.2004.04.006

Krapp A, David LC, Chardin C, Girin T, Marmagne A, Leprince AS, Chaillou S, Ferrario-Méry S, Meyer C, Daniel-Vedele F (2014) Nitrate transport and signalling in Arabidopsis. J Exp Bot 65:789-798. doi:10.1093/jxb/eru001

Kutílek M, Nielsen DR (2015) Soil. The skin of the planet Earth. Springer, Dordrecht, p 239. doi:10.1007/978-94-017-9789-4

Lasken RS (2012) Genomic sequencing of uncultured microorganisms from single cells. Nat Rev Microbiol 10:631-640. doi:10. 1038/nrmicro2857

Li ESY, Liu WT (2003) DNA microarray technology in microbial ecology studies-principle, applications and current limitations. Microbes Environ 18:175-187. doi:10.1264/jsme2.18.175
Li J, Dai X, Liu T, Zhao PX (2012) LegumeIP: an integrative database for comparative genomics and transcriptomics of model legumes. Nucleic Acids Res 40:D1221-D1229. doi:10.1093/nar/ gkr939

Li F, Fan G, Lu C, Xiao G, Zou C, Kohel RJ, Ma Z, Shang H, Ma X, Wu J, Liang X, Huang G, Percy RG, Liu K, Yang W, Chen W, Du X, Shi C, Yuan Y, Ye W, Liu X, Zhang X, Liu W, Wei H, Wei S, Huang G, Zhang X, Zhu S, Zhang H, Sun F, Wang X, Liang J, Wang J, He Q, Huang L, Wang J, Cui J, Song G, Wang K, Xu X, Yu JZ, Zhu Y, Yu S (2015) Genome sequence of cultivated upland cotton (Gossypium hirsutum TM-1) provides insights into genome evolution. Nat Biotechnol 33:524-530. doi: $10.1038 /$ nbt. 3208

Lindbo DL, Kozlowski DA, Robinson C (2012) Know soil know life. Soil Science Society of America, Madison, p 206. doi:10.2136/ 2012.knowsoil

Liu Y, Shi L, Ye N, Liu R, Jia W, Zhang J (2009) Nitric oxideinduced rapid decrease of abscisic acid concentration is required in breaking seed dormancy in Arabidopsis. New Phytol 183:1030-1042. doi:10.1111/j.1469-8137.2009.02899.x

Loman NJ, Constantinidou C, Chan JZM, Halachev M, Sergeant M, Penn CW, Robinson ER, Pallen MJ (2012) High-throughput bacterial genome sequencing: an embarrassment of choice, a world of opportunity. Nat Rev Microbiol 10:599-606. doi:10. 1038/nrmicro2850

López-Arredondo DL, Herrera-Estrella L (2012) Engineering phosphorus metabolism in plants to produce a dual fertilization and weed control system. Nat Biotechnol 30:889-893. doi:10.1038/ nbt. 2346

López-Arredondo DL, Leyva-González MA, González-Morales SI, López-Bucio J, Herrera-Estrella L (2014) Phosphate nutrition: improving low-phosphate tolerance in crops. Annu Rev Plant Biol 65:95-123. doi:10.1146/annurev-arplant-050213-035949

Loqué D, von Wirén N (2004) Regulatory levels for the transport of ammonium in plant roots. J Exp Bot 55:1293-1305. doi:10.1093/ jxb/erh147

Lorenz P, Eck J (2005) Metagenomics and industrial applications. Nat Rev Microbiol 3:510-516. doi:10.1038/nrmicro1161

Louche J, Ali MA, Cloutier-Hurteau B, Sauvage FX, Quiquampoix H, Plassard C (2010) Efficiency of acid phosphatases secreted from the ectomycorrhizal fungus Hebeloma cylindrosporum to hydrolyse organic phosphorus in podzols. FEMS Microbiol Ecol 73:323-335. doi:10.1111/j.1574-6941.2010.00899.x

Magi A, Benelli M, Gozzini A, Girolami F, Torricelli F, Brandi ML (2010) Bioinformatics for next generation sequencing data. Genes 1:294-307. doi:10.3390/genes1020294

Mardis ER (2008) Next-generation DNA sequencing methods. Annu Rev Genomics Hum Genet 9:387-402. doi:10.1146/annurevanchem-062012-092628

Markowitz VM, Chen IMA, Palaniappan K, Chu K, Szeto E, Pillay M, Ratner A, Huang J, Woyke T, Huntemann M, Anderson I, Billis K, Varghese N, Mavromatis K, Pati A, Ivanova NN, Kyrpides NC (2014) IMG 4 version of the integrated microbial genomes comparative analysis system. Nucleic Acids Res 42:D560-D567. doi:10.1093/nar/gkt963

Meena VS, Maurya BR, Verma JP (2014) Does a rhizospheric microorganism enhance $\mathrm{K}^{+}$availability in agricultural soils? Microbiol Res 169:337-347. doi:10.1016/j.micres.2013.09.003

Meena VS, Maurya BR, Verma JP, Aeron A, Kumar A, Kim K, Bajpai VK (2015) Potassium solubilizing rhizobacteria (KSR): isolation, identification, and K-release dynamics from waste mica. Ecol Eng 81:340-347. doi:10.1016/j.ecoleng.2015.04.065

Michael TP, VanBuren R (2015) Progress, challenges and the future of crop genomes. Curr Opin Plant Biol 24:71-81. doi:10.1016/j. pbi.2015.02.002 
Mills DEK, Entry JA, Gillevet PM, Mathee K (2007) Assessing microbial community diversity using amplicon length heterogeneity polymerase chain reaction. Soil Sci Soc Am J 71:572-578. doi:10.2136/sssaj2006.0147

Mirete S, de Figueras CG, González-Pastor JE (2007) Novel nickel resistance genes from the rhizosphere metagenome of plants adapted to acid mine drainage. Appl Environ Microbiol 73:6001-6011. doi:10.1128/AEM.00048-07

Mission J, Raghotham KG, Jain A, Jouhet J, Block MA, Bligny R, Ortet P, Creff A, Somerville S, Rolland N, Doumas N, Nacry P, Herrera-Estrella L, Nussaume L, Thibuaud MC (2005) A genome-wide transcriptional analysis using Arabidopsis thaliana Affymetrix gene chips determined plant responses to phosphate deprivation. Proc Natl Acad Sci USA 102:11934-11939. doi:10. 1073/pnas.0505266102

Mohammadi K (2012) Phosphorus Solubilizing Bacteria: occurrence, mechanisms and their role in crop production. Res Environ 2:80-85. doi:10.5923/j.re.20120201.10

Morcuende R, Bari R, Gibon Y, Zheng W, Pant BD, Bläsing R, Usadel B, Czechowski T, Udvardi MK, Stitt M, Scheible WR (2007) Genome-wide reprogramming of metabolism and regulatory networks of Arabidopsis in response to phosphorus. Plant Cell Environ 30:85-112. doi:10.1111/j.1365-3040.2006.01608.x

Moter A, Göbel UB (2000) Fluorescence in situ hybridization (FISH) for direct visualization of microorganisms. J Microbiol Methods 41:85-112. doi:10.1016/S0167-7012(00)00152-4

Murray AE, Lies D, Li G, Nealson K, Zhou J, Tiedje JM (2001) DNA/DNA hybridization to microarrays reveals gene-specific differences between closely related microbial genomes. Proc Natl Acad Sci USA 98:9853-9858. doi:10.1073/pnas.171178898

Newbury HJ, Ford-Lloyd BV (1993) The use of RAPD for assessing variation in plants. Plant Growth Regul 12:43-51. doi:10.1007/ BF00144581

Nobandegani MBJ, Saud HM, Yun WM (2015) Phylogenetic relationship of phosphate solubilizing bacteria according to 16S rRNA genes. Biomed Res Int 2015:201379. doi:10.1155/ 2015/201379

Nocker A, Burr M, Camper AK (2007) Genotypic microbial community profiling: a critical technical review. Microb Ecol 54:276-289. doi:10.1007/s00248-006-9199-5

Ocio JA, Brookes PC (1990) An evaluation of methods for measuring the microbial biomass in soils following recent additions of wheat straw and the characterization of the biomass that develops. Soil Biol Biochem 22:685-694. doi:10.1016/00380717(90)90016-S

Ohkama-Ohtsu N, Wasaki J (2010) Recent progress in plant nutrition research: cross-talk between nutrients, plant physiology and soil microorganisms. Plant Cell Physiol 51:1255-1264. doi:10.1093/ pcp/pcq095

Okubo A, Sugiyama S (2009) Comparison of molecular fingerprinting methods for analysis of soil microbial community structure. Ecol Res 24:1399-1405. doi:10.1007/s11284-009-0602-9

Ouziad F, Wilde P, Schmelzer E, Hildebrandt U, Bothe H (2006) Analysis of expression of aquaporins and $\mathrm{Na}^{+} / \mathrm{H}^{+}$transporters in tomato colonized by arbuscular mycorrhizal fungi and affected by salt stress. Environ Exp Bot 57:177-186. doi:10.1016/j. envexpbot.2005.05.011

Oyarburo NS, Machinandiarena MF, Feldman ML, Daleo GR, Andreu AB, Olivieri FP (2015) Potassium phosphite increases tolerance to UV-B in potato. Plant Physiol Biochem 88:1-8. doi:10.1016/j.plaphy.2015.01.003

Pérez-Tienda J, Testillano PS, Balestrini R, Fiorilli V, Azcón-Aguilar C, Ferrol N (2011) GintAMT2, a new member of the ammonium transporter family in the arbuscular mycorrhizal fungus Glomus intraradices. Fungal Genet Biol 48:1044-1055. doi:10.1016/j. fgb.2011.08.003
Pérez-Tienda J, Corrêa A, Azcón-Aguilar C, Ferrol N (2014) Transcriptional regulation of host transporters and GS/GOGAT pathway in arbuscular mycorrhizal rice roots. Plant Physiol Biochem 75:1-8. doi:10.1016/j.plaphy.2013.11.029

Pich A, Manteuffel R, Hillmer S, Scholz G, Schmidt W (2001) Fe homeostasis in plant cells: does nicotianamine play multiple roles in the regulation of cytoplasmic Fe concentration? Planta 213:967-976. doi:10.1007/s004250100573

Plassard C, Dell B (2010) Phosphorus nutrition of mycorrhizal trees. Tree Physiol 30:1129-1139. doi:10.1093/treephys/tpq063

Poirier Y, Bucher M (2002) Phosphate transport and homeostasis in Arabidopsis. In: Somerville CR, Meyerowitz EM (eds) The Arabidopsis book. The American Society of Plant Biologists, Rockville, pp 1-35. doi:10.1199/tab.0024

Prescott CE, Grayston SJ (2013) Tree species influence on microbial communities in litter and soil: current knowledge and research needs. For Ecol Manag 309:19-27. doi:10.1016/j.foreco.2013. 02.034

Rajendhran J, Gunasekaran P (2008) Strategies for accessing soil metagenome for desired applications. Biotechnol Adv 26:576-590. doi:10.1016/j.biotechadv.2008.08.002

Rajesh T, Rajendhran J, Gunasekaran P (2012) Genomic technologies in environmental bioremediation. In: Satyanarayana T, Johri BN, Prakash A (eds) Microorganisms in environmental management: microbes and environment. Springer, Heidelberg, p 819. doi:10. 1007/978-94-007-2229-3_31

Rastogi G, Sani RK (2011) Molecular techniques to assess microbial community structure, function, and dynamics in the environment. In: Ahmad I, Ahmad F, Pichtel J (eds) Microbes and microbial technology: 29. Agricultural and environmental applications. Springer, New York, pp 29-57. doi:10.1007/9781-4419-7931-5_2.Springer2011

Reddy PP (2014) Potential role of PGPR in agriculture. In: Reddy PP (ed) Plant growth promoting Rhizobacteria for horticultural crop protection. Springer, India, pp 17-34. doi:10.1007/978-81-3221973-6_2

Renella G, Ogunseitan O, Giagnoni L, Arenella M (2014) Environmental proteomics: a long march in the pedosphere. Soil Biol Biochem 69:34-37. doi:10.1016/j.soilbio.2013.10.035

Rincon-Florez VA, Carvalhais LC, Schenk PM (2013) Cultureindependent molecular tools for soil and rhizosphere microbiology. Diversity 5:581-612. doi:10.3390/d5030581

Russo SE, Legge R, Weber KA, Brodie EL, Goldfarb KC, Benson AK, Tan S (2012) Bacterial community structure of contrasting soils underlying Bornean rain forests: inferences from microarray and next-generation sequencing methods. Soil Biol Biochem 55:48-59. doi:10.1016/j.soilbio.2012.05.021

Salzberg SL, Phillippy AM, Zimin A, Puiu D, Magoc T, Koren S, Treangen TJ, Schatz MC, Delcher AL, Roberts M, Marçais G, Pop M, Yorke JA (2012) GAGE: a critical evaluation of genome assemblies and assembly algorithms. Genome Res 22:557-567. doi:10.1101/gr.131383.111

Santi C, Bogusz D, Franche C (2013) Biological nitrogen fixation in non-legume plants. Ann Bot 111:743-767. doi:10.1093/aob/ met048

Sato S, Nakamura Y, Kaneko T, Asamizu E, Kato T, Nakao M, Sasamoto S, Watanabe S, Ono A, Kawashima K, Fujishiro T, Katoh M, Kohara M, Kishida Y, Minami C, Nakayama S, Nakazaki N, Shimizu Y, Shinpo S, Takahashi C, Wada T, Yamada M, Ohmido N, Hayashi M, Fukui F, Baba T, Nakamichi T, Mori H, Tabata S (2008) Genome structure of the legume, Lotus japonicus. DNA Res 15:227-239. doi:10.1093/dnares/ dsn008

Schadt EE, Turner S, Kasarskis A (2010) A window into thirdgeneration sequencing. Hum Mol Genet 19:R227-R240. doi:10. 1093/hmg/ddq416 
Schatz MC, Witkowski J, McCombie WR (2012) Current challenges in de novo plant genome sequencing and assembly. Genome Biol 13:243. doi:10.1186/gb-2012-13-4-243

Schoebitz M, Ceballos C, Ciampi L (2013) Effect of immobilized phosphate solubilizing bacteria on wheat growth and phosphate uptake. J Soil Sci Plant Nutr 13:1-10. doi:10.4067/S071895162013005000001

Servín-Garcidueñas LE, Rogel MA, Ormeño-Orrillo E, DelgadoSalinas A, Martínez-Romero J, Sánchez F, Martínez-Romero E (2012) Genome sequence of Rhizobium sp. strain CCGE510, a symbiont isolated from nodules of the endangered wild bean Phaseolus albescens. J Bacteriol 194:6310-6311. doi:10.1128/ JB.01536-12

Sessitsch A, Weilharter A, Gerzabeck MH, Kirchmann H, Kandeler E (2001) Microbial population structure in soil particle size fractions of a long-term fertilizer field experiment. Appl Environ Microbiol 67:4215-4224. doi:10.1128/AEM.67.9.4215-4224. 2001

Sharma T, Dreyer I, Riedelsberger J (2013) The role of $\mathrm{K}^{+}$channels in uptake and redistribution of potassium in the model plant Arabidopsis thaliana. Front Plant Sci 4:224. doi:10.3389/fpls. 2013.00224

Sheng XF (2005) Growth promotion and increased potassium uptake of cotton and rape by a potassium releasing strain of Bacillus edaphicus. Soil Biol Biochem 37:1918-1922. doi:10.1016/j. soilbio.2005.02.026

Shokralla S, Spall JL, Gibson JF, Hajibabaei M (2012) Nextgeneration sequencing technologies for environmental DNA research. Mol Ecol 21:1794-1805. doi:10.1111/j.1365-294X. 2012.05538.x

Singh B, Satyanarayana T (2011) Microbial phytases in phosphorus acquisition and plant growth promotion. Physiol Mol Biol Plants 17:93-103. doi:10.1007/s12298-011-0062-x

Smith CJ, Osborn AM (2009) Advantages and limitations of quantitative PCR (qPCR)-based approaches in microbial ecology. FEMS Microbiol Ecol 67:6-20. doi:10.1111/j.1574-6941. 2008.00629.x

Smith VH, Schindler DW (2009) Eutrophication science: where do we go from here? Trends Ecol Evol 24:201-207. doi:10.1016/j. tree.2008.11.009

Stewart EJ (2012) Growing unculturable bacteria. J Bacteriol 194:4151-4160. doi:10.1128/JB.00345-12

Sun S, Chen J, Li W, Altintas I, Lin A, Peltier S, Stocks K, Allen EE, Ellisman M, Grethe J, Wooley J (2011) Community cyberinfrastructure for advanced microbial ecology research and analysis: the CAMERA resource. Nucleic Acids Res 39:D546D551. doi:10.1093/nar/gkq1102

Takei K, Sakakibara H, Taniguchi M, Suguyama T (2001) Nitrogendependent accumulation of cytokinins in root and the translocation to leaf: implication of cytokinin species that induces gene expression of maize response regulator. Plant Cell Physiol 42:85-93. doi:10.1093/pcp/pce009

Thamdrup B (2012) New pathways and processes in the global nitrogen cycle. Annu Rev Ecol Evol Syst 43:407-428. doi:10. 1146/annurev-ecolsys-102710-145048

Van Nostrand JD, He Z, Zhou J (2011) New developments and applications of microarrays for microbial community analysis in natural and impacted ecosystems. In: Moo-Young M (ed) Comprehensive biotechnology. Elsevier, Amsterdam, pp 37-45

Vance CP (2001) Symbiotic nitrogen fixation and phosphorus acquisition. Plant nutrition in a world of declining renewable resources. Plant Physiol 127:390-397. doi:10.1104/pp.010331

Vance CP, Uhde-Stone C, Allan DL (2003) Phosphorus acquisition and use: critical adaptations by plants for securing a nonrenewable resource. New Phytol 157:423-447. doi:10.1046/j.14698137.2003.00695.x
Vassileva M, Serrano M, Bravo V, Jurado E, Nikolaeva I, Martos V, Vassilev N (2010) Multifunctional properties of phosphatesolubilizing microorganisms grown on agro-industrial wastes in fermentation and soil conditions. Appl Microbiol Biotechnol 85:1287-1299. doi:10.1007/s00253-009-2366-0

Versaw WK, Harrison MJ (2002) A chloroplast phosphate transporter, PHT2; 1, influences allocation of phosphate within the plant and phosphate-starvation responses. Plant Cell 14:1751-1766. doi:10.1105/tpc.002220

Véry AA, Nieves-Cordones M, Daly M, Khan I, Fizames C, Sentenac $\mathrm{H}$ (2014) Molecular biology of $\mathrm{K}^{+}$transport across the plant cell membrane: what do we learn from comparison between plant species? J Plant Physiol 171:748-769. doi:10.1016/j.jplph.2014. 01.011

von Wirén N (2011) Grand challenges in plant nutrition. Front Plant Sci 2:4. doi:10.3389/fpls.2011.00004

von Wittgenstein NJJB, Le CH, Hawkins BJ, Ehlting J (2014) Evolutionary classification of ammonium, nitrate, and peptide transporters in land plants. BMC Evol Biol 14:11. doi:10.1186/ 1471-2148-14-11

Wang R, Okamoto M, Xing X, Crawford NM (2003) Microarray analysis of the nitrate response in Arabidopsis roots and shoots reveals over 1000 rapidly responding genes and new linkages to glucose, trehalose-6-phosphate, iron, and sulfate metabolism. Plant Physiol 132:556-567. doi:10.1104/pp.103.021253

Wang M, Shen Q, Xu G, Guo S (2014a) New insight into the strategy for nitrogen metabolism in plant cells. Int Rev Cell Mol Biol 310:1-37. doi:10.1016/B978-0-12-800180-6.00001-3

Wang G, Zhang C, Battle S, Lu H (2014b) The phosphate transporter PHT4;1 is a salicylic acid regulator likely controlled by the circadian clock protein CCA1. Front Plant Sci 5:701. doi:10. 3389/fpls.2014.00701

Wasaki J, Shinano T, Onishi K, Yonetani R, Yazaki J, Fuji F, Shimbo K, Ishikawa M, Shimatani Z, Nagata Y, Hashimoto A, Ohta T, Sato Y, Miyamoto C, Honda S, Kojima K, Sasaki T, Kishimoto N, Kikuchi S, Osaki M (2006) Transcriptomic analysis indicates putative metabolic changes caused by manipulation of phosphorus availability in rice leaves. J Exp Bot 57:2049-2059. doi:10. 1093/jxb/erj158

Wu Y, He Y, Yin H, Chen W, Wang Z, Xu L, Zhang A (2012a) Isolation of phosphate-solubilizing fungus and its application in solubilization of rock phosphates. Pak J Biol Sci 15:1144-1151. doi:10.3923/pjbs.2012.1144.1151

Wu Z, Guo L, Qin S, Li C (2012b) Encapsulation of R. planticola Rs2 from alginate-starch-bentonite and its controlled release and swelling behavior under simulated soil conditions. J Ind Microbiol Biotechnol 39:317-327. doi:10.1007/s10295-011-1028-2

Xiong H, Shen H, Zhang L, Zhang Y, Guo X, Wang P, Duan P, Ji C, Zhong L, Zhang F, Zuo Y (2013) Comparative proteomic analysis for assessment of the ecological significance of maize and peanut intercropping. J Proteomics 78:447-460. doi:10. 1016/j.jprot.2012.10.013

Xu G, Fan X, Miller AJ (2012) Plant nitrogen assimilation and use efficiency. Annu Rev Plant Biol 63:153-182. doi:10.1146/ annurev-arplant-042811-105532

Yadav UP, Ayre BG, Bush DR (2015) Transgenic approaches to altering carbon and nitrogen partitioning in whole plants: assessing the potential to improve crop yields and nutritional quality. Front Plant Sci 6:275. doi:10.3389/fpls.2015.00275

Zaidi A, Khan MS, Ahemad M, Oves M (2009) Plant growth promotion by phosphate solubilizing bacteria. Acta Microbiol Immunol Hung 56:263-284. doi:10.1556/AMicr.56.2009.3.6

Zhang QC, Wang GH, Yao HY (2007) Phospholipid fatty acid patterns of microbial communities in paddy soil under different fertilizer treatments. J Environ Sci 19:55-59. doi:10.1016/ S1001-0742(07)60009-6 
Zhou J, Xia B, Treves DS, Wu LY, Marsh TL, O’Neill RV, Palumbo AV, Tiedje JM (2002) Spatial and resource factors influencing high microbial diversity in soil. Appl Environ Microbiol 68:326-334. doi:10.1128/AEM.68.1.326-334.2002
Zörb C, Senbayram M, Peiter E (2014) Potassium in agriculturestatus and perspectives. J Plant Physiol 171:656-669. doi:10. 1016/j.jplph.2013.08.008 